\title{
Völd og valdafíkn
}

\section{Torfi Magnússon}

taugalæknir,

taugalækningadeild,

Landspítala

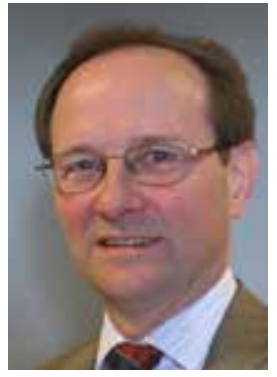

torfimag@landspitali.is pví pá sem standa í stórræðum. Testósterón eykur einnig virkni dópamíns í heilanum.

Dópamín er efni vellíðunar. Allar tegundir verðlauna sem rannsakaðar hafa verið auka virkni dópamíns í heilanum og pað stuðlar að peirri vellíðan og sigurvímu sem fylgir sætum sigri og sigursæll leiðtogi finnur í upphafi fyrir hinum jákvæðu áhrifum og vellíðan. Dópamín miðlar pó ekki eingöngu jákvæðum áhrifum pví pað tengist mjög spennu og fíkn. Ýmsir vímugjafar auka virkni dópamíns í heila, svo sem áfengi, amfetamín og kókaín, og segja má að dópamín sé miðill fíknarinnar. Efnafræðileg breyting getur orðið hjá vellukkuðum valdamanni og sigurvegara og orsakað valdavímu sem hjálpar viðkomandi að takast á við áskoranir. En eins og með aðra vímu getur myndast pol og sífellt stærri skammta og fleiri sigra parf pá til að ná sömu áhrifum. Auk valdavímunnar getur próast valdafíkn. Hvort úr verður hreinn valdhroki ræðst af fleiri páttum, meðal annars tímalengd valda og valdapörf einstaklingsins.

Öll höfum við valdapörf, í peim skilningi að vilja hafa áhrif á aðra. Valdapörf hefur áhrif á stjórnunarstíl ${ }^{4}$ og ráðherrar sem hafa mikla valdapörf stýra einatt með lítilli hirð samstarfsfólks og sniðganga samstarfsráðherra og ráðgefandi nefndir. Ákvarðanataka slíkra ráðamanna er oft hröð. Peir sem hafa minni valdapörf stýra hins vegar fremur með valddreifingu og leita sameiginlegrar niðurstöðu með samstarfsfólki. Hjá peim tekur lengri tíma að ná fram lokaniðurstöðu en meiri líkur eru á að sátt náist.

Valdapörf getur verið af tvennum toga. Annars vegar pað sem nefna má persónutengda valdapörf (p-valdapörf) par sem leiðtoginn horfir ekki síst til pess sem getur orðið honum sjálfum til hagsbóta. Hins vegar samfélagstengd valdapörf (s-valdapörf) par sem fyrst og fremst er horft til pess ávinnings sem samfélaginu getur hlotnast fyrir tilstilli valdamannsins. Mikil s-valdapörf er af hinu góða fyrir samfélagið og minnkar jafnframt hina persónutengdu valdpörf. Аð um raunverulegt fyrirbæri er að ræða styðst við rannsóknir sem sýna að karlar með hæstu p-valdapörfina hækka

að jafnaði mest í testósteróni pegar sig- ur vinnst. ${ }^{5}$ Einnig má nefna að s-valdapörf kvenna virðist að jafnaði meiri en p-tegundin.

Valdavíman kann að vera mikilvæg, jafnvel nauðsynleg leiðtoga undir miklu álagi. Hún eykur sjálfsöryggi og einbeitingu, dregur úr streitu og léttir álagið sem fylgir völdum og auðveldar ákvarðanatöku. Hins vegar getur valdavíman leitt leiðtogann inn í vítahring. Til að viðhalda vellíðaninni parf síendurtekið flæði testósteróns og dópamíns og pað kallar á sífellt nýja sigra. Úr verður fíkn, valdafíkn. Hitti valdafíknin á sjálfmiðaðan einstakling með mikla pörf fyrir persónutengd völd sprettur upp valdhroki. Valdhrokanum fylgir spilling og fleiri lestir.

Góður leiðtogi parf að vera fremstur meðal jafningja. Hann verður að hafa vilja til valda og njóta pess að hafa völd, pví til lítils er sá leiðtogi sem engin völd vill hafa og enga sigra vinna. En sigurviljinn parf аð vera fyrir "okkur" en ekki fyrst og fremst fyrir "mig“.

Valdamikill leiðtogi, fullur valdhroka er heiminum hættulegur. Lýðræði var innleitt í Grikklandi sem svar við valdhroka og spillingu og til að takmarka valdatíma leiðtoga. Stjórnarskrárbundin takmörkun á valdatíma leiðtoga nútímans getur stutt við sama markmið.

\section{Heimildir}

1. Wright ND, Bahrami B, Johnson E, Di Malta G, Rees G, Frith $\mathrm{CD}$, et al. Testosterone disrupts human collaboration by increasing egocentric choices. Proc Biol Sci 2012; 279: 2275-80.

2. Bernhardt PC, Dabbs JM Jr, Fielden JA, Lutter CD. Testosterone changes during vicarious experiences of winning and losing among fans at sporting events. Physiol Behav 1998; 65: 59-62.

3. Coates JM, Gurnell M, Sarnyal Z. From molecule to market: steroid hormones and financial risk-taking. Philos Trans R Soc Lond B Biol Sci 2010; 365: 331-43.

4. Hermann MG. Assessing leadership style: A trait analysis. Originally Published November 1999 Minor revision 200211-13, @ 1999, 2002 by Social Science Automation, Inc.

5. Schultheiss OC, Campbell KL, McClelland DC. Implicit power motivation moderates men's testosterone responses to imagined and real dominance success. Horm Behav 1999; 36: 234-41. viðskiptum. ${ }^{3}$ Pótt ekki hafi verið ar rannsóknir á stjórnmálamönnum (peir gefa lítið færi á sér), má gera ráð fyrir að kosningasigrar og klapp stuðningsmanna hafi sambærileg áhrif. Testósterón eykur einbeitingu, álagspol, keppnisvilja og viljann til valda. Рað minnkar kvíða og styrkir
Intoxication of power

Torfi Magnússon MD, Neurologist Dptm. of Neurology Landspitali University Hospital 